\title{
Internet addiction update: diagnostic criteria, assessment and prevalence
}

\author{
Roberto Poli ${ }^{\dagger, 1}$
}

\begin{abstract}
In the last 15 years, Internet use has grown tremendously: now approximately $40 \%$ of the world population is online. Internet addiction is an emergent disorder, because the increasing popularity has led to the emergence of clinical cases presenting abuse symptoms. The classification of Internet Addiction is still controversial and there are several diagnostic criteria and various tools of measure. However there are no widely accepted diagnostic criteria.
\end{abstract}

Prevalence estimates vary widely, although we can estimate the internet addiction prevalence in the general adult population as approximately $2 \%$.

\section{Keywords}

Internet addiction, Pathological internet use, Behavioral addiction, Prevalence addiction

\section{Introduction}

The word addiction comes from Latin addictus, which means excessively devoted to something with loss of ability to choose freely or slave.

In recent years, the term addiction has been expanded beyond substance dependence to include non-substance-related behaviors that cause problems and impairment [1].

Addiction to a substance and addiction to a behavior may look similar in their effects on behavioral patterns, emotions and physiology [2].

The first type, substance addiction, involves direct manipulation of pleasure using products legal or illegal that is ingested into the body, including drug use disorders and food-related disorders.

The second type, behavioral or process addiction comprises a series of potentially pathological behaviors that expose individuals to moodalternating events by which they achieve pleasure and become dependent [3].
There are several types of behavioral addiction including Internet use, gambling, sex, love, exercise, work, shopping [4].

Over the last 15 years, Internet use has grown very quickly: in contemporary society approximately $40 \%$ of the world population is online. Internet is an important tool for education, entertainment, communication and information-sharing [5].

The increasing popularity and frequency of internet use has led to the emergence of clinical cases presenting abuse symptoms [6].

The pathway from adaptive to pathological Internet use appears to be ambiguous and there are no widely accepted diagnostic criteria [7].

The clinical features of behavioral problems Internet-related have been described in various terms, including Internet addiction disorder, pathological internet use (PIU), problematic Internet use, excessive Internet use, Internet dependence, compulsive computer use and virtual addiction [8]. 
The appropriate classification of Internet addiction is still controversial. It was classified as impulse-control disorder or as obsessivecompulsive disorder or as behavior addiction [9]. The inclusion of Internet Gaming Disorder in the appendix of the updated version of the Diagnostic and Statistical Manual for Mental Disorders (DSM-5) encourages further research [10].

The diagnostic criteria of Internet Gaming Disorder situates the behavior within the category of "Non-substance addictions" and suggests that Internet addiction might be one of the candidates for this category as is Pathological Gambling [11].

Several diagnostic criteria for Internet addiction have been proposed and the most popular are shown in Table 1.

Within the Internet Addiction phenomenon, five subtypes have been classified, because the people tipically become addicted to a particular application that acts as a trigger for excessive Internet use [12].

- Cybersexual addiction: individuals are engaged in viewing, downloading and trading online pornography

- Cyber-relational addiction: people become overly involved in online relationship, more important than real life ones, with marital discord and family instability (chat-rooms, social networks)

- Net compulsions: gambling, shopping, trading online

- Information overload: excessive web surfing and information and database search

- Computer addiction: individuals are overly engaged with pre-programmed games

\section{Aim and method}

The aim of this paper is to review the internet addiction research with regard to diagnostic criteria, tools for assessment and prevalence in general adult population, in order to answer the following questions:

i) What is internet addiction? ii) How it assessed? iii) How common is in general adult population? iv) Are there geographical differences or environmental risk factors? and v) is internet addiction a disorder?
In order to answer this questions a literature search was conducted using the database PubMed, PsycInfo, Scopus and Google Scholar using the following key-words: internet addiction, pathological internet use, behavioral addiction, prevalence addiction.

The studies were selected on the basis on the following inclusion criteria: i) contain quantitative empirical data ii) include a minimum of 1000 participants and iii) provide a full-text article published in English. There were no restrictions on time or publication status.

\section{Assessment}

Several instruments for Internet addiction assessment have been developed, but none have emerged as the "gold standard" [8].

The most commonly used ones are the Internet addiction test (IAT), the Young of the Internet Addiction Questionnaire (YDQI), the Chen's Internet addiction scale (CIAS) and the Internet addiction scale (IAS).

The IAT is a 20 -item self-report scale that rates degree of compulsive use, loss of control, negative consequences and neglecting everyday life. The IAT is based on a Likert scale from 1 ("not at all") to 5 ("always"), is valid and reliable, with satisfactory internal consistency (Cronbach's alpha of .84). Respondents with scores between 40-69 were classified as "addicted" and respondents with scores higher than 69 were classified as "possibly addicted" [12]. The IAT is a revised version of the IDQI, a 8 item self-report measure scored dichotomously and based on the diagnostic symptoms of pathological gambling: preoccupation, tolerance, loss of control, withdrawal, negative consequences, denial, staying online longer than originally intended and escapism. The criteria are evaluated through eight yes or no questions with a total score ranging $0-8$. Those scoring $\geq$ 5 were classified as pathological [12].

The CIAS is a 26-item self-report validated measure, scored on a 4-point Likert scale, which rates five dimensions: compulsive use, tolerance, withdrawal problems with interpersonal relationship and time management [13-15]. Furthermore, the scale investigates weekly online hours and personal experience of the Internet use. The internal consistency of the scale is very satisfactory, with Cronbach's alpha values between .79 to .93 for the respective subscales. 
Respondents with scores higher than 69 were classified as "addicted" [16]. It has also been reported that the screening cut-off of 58 points has high sensitivity but low specificity.

The IAS is a validate scale, based on combination of Young's and Beard's Internet addiction criteria, including preoccupation, loss of control, tolerance, withdrawal, deception, overall impairment and escapism. It's a 20 items scored on a 4-point Likert scale with following scoring: 48-52 potential risk and 53/80 high risk for Internet addiction. The internal consistency is not registered [17].

\section{Prevalence}

The epidemiological findings of Internet addiction are shown in Table 2.

Prevalence studies have reported large variations (from $0.7 \%$ to $27.7 \%$ ). These differences in the prevalence of Internet addiction were due to diverse study design, different assessment methods, and sampling from different subpopulation in various studies [18-24]. Most importantly, a wide variety of scales have been applied to assess Internet addiction, sometime with the use of different cut-off points on the same measures across studies. Besides, the studies focus on younger population rather than the wider adult population [25].

In conclusion, we can estimate the internet addiction prevalence in the general adult population as approximately $2 \%$ [4].

The data prevalence show differences between geographical areas: in fact, many studies show that internet addiction was prevalent in Asian samples [26,27]. It might suggest that and environmental factors were associated factors for Internet addiction [28].

Various factors have been found to be statistically related with Internet addiction [29,30]. The strongest evidences are for the following variables: younger age, male gender, early exposure to the Internet and frequency use, availability of time $[31,32]$.

\section{Conclusions}

The Internet use has radically changed our lives, more so than any other technological medium, yet we still know comparatively little about its effects on our psychological functioning, mental health and well-being. The more recent introduction of mobile devices (smartphones)

\begin{tabular}{|c|c|c|c|}
\hline Young [12] & Griffiths [13] & Block [14] & Tao [15] \\
\hline preoccupation & salience & $\begin{array}{l}\text { excessive use with a } \\
\text { loss of sense of time }\end{array}$ & $\begin{array}{l}\text { preoccupation and } \\
\text { withdrawal }\end{array}$ \\
\hline $\begin{array}{l}\text { mood change when } \\
\text { attempting to stop Internet } \\
\text { usage }\end{array}$ & $\begin{array}{l}\text { mood } \\
\text { modification }\end{array}$ & $\begin{array}{l}\text { adverse } \\
\text { consequences }\end{array}$ & functional impairment \\
\hline $\begin{array}{l}\text { the need to use Internet for } \\
\text { increasing amounts of time }\end{array}$ & tolerance & tolerance & $\begin{array}{l}\text { Duration of at least } 3 \\
\text { months } \\
\text { At least } 6 \text { hours of } \\
\text { non-business Internet } \\
\text { use per day }\end{array}$ \\
\hline $\begin{array}{l}\text { unsuccessful efforts to stop } \\
\text { using Internet }\end{array}$ & withdrawal & withdrawal & \multirow{5}{*}{$\begin{array}{l}\text { One or more: } \\
\text { tolerance, } \\
\text { unsuccessful efforts to } \\
\text { control use, continued } \\
\text { use despite problems, } \\
\text { loss of other interests, } \\
\text { use to escape or } \\
\text { relieve disphoric mood }\end{array}$} \\
\hline $\begin{array}{l}\text { staying online longer than } \\
\text { intended }\end{array}$ & conflict & & \\
\hline lying about Internet use & relapse & & \\
\hline $\begin{array}{l}\text { jeopardizing of significant } \\
\text { relationship or opportunities }\end{array}$ & & & \\
\hline $\begin{array}{l}\text { escape from problems or } \\
\text { seeking to relieve bad mood } \\
\text { states }\end{array}$ & & & \\
\hline
\end{tabular}

\begin{tabular}{|c|c|c|c|c|c|}
\hline \multicolumn{2}{|r|}{ Author, Year } & \multirow{2}{*}{$\begin{array}{c}\text { Sample } \\
4311 \text { people aged } \\
15-19\end{array}$} & \multirow{2}{*}{$\begin{array}{c}\text { Country } \\
\text { Turkey }\end{array}$} & \multirow{2}{*}{$\begin{array}{c}\text { Assessment } \\
\text { IAT }\end{array}$} & \multirow{2}{*}{$\begin{array}{c}\text { Results } \\
5 \% \text { addicted }\end{array}$} \\
\hline 1 & Ak et al., 2013 [18] & & & & \\
\hline 2 & Anderson, 2001 [19] & $\begin{array}{c}1302 \text { people aged } \\
18-22\end{array}$ & US & IAT & $8.1 \%$ addicted \\
\hline 3 & $\begin{array}{c}\text { Bakken et al..., } 2009 \\
{[20]}\end{array}$ & $\begin{array}{c}3399 \text { people aged } \\
16-74\end{array}$ & Norvay & YDQI & $1.0 \%$ addicted \\
\hline 4 & Cao et al., 2006 [21] & $\begin{array}{c}2620 \text { people aged } \\
12-18\end{array}$ & China & YDQI & $2.4 \%$ addicted \\
\hline 5 & $\begin{array}{c}\text { Demetrovics et al., } \\
2008 \text { [22] }\end{array}$ & 1037 adults & Hungary & IAT-YDQI & $4.3 \%$ addicted \\
\hline 6 & Kim et al.., 2006 [23] & $\begin{array}{c}1573 \text { people aged } \\
15-16\end{array}$ & South Korea & IAS & $1.6 \%$ addicted \\
\hline 7 & Ko et al., 2009 [24] & $\begin{array}{c}2162 \text { people aged } \\
11-13\end{array}$ & Taiwan & $\mathrm{CIAS}$ & $10.8 \%$ addicted \\
\hline 8 & Ni et al., 2009 [25] & $\begin{array}{c}3557 \text { people aged } \\
18-22\end{array}$ & China & IAT & $6.44 \%$ addicted \\
\hline 9 & Poli et al.., 2012 [26] & $\begin{array}{c}2533 \text { people aged } \\
14-21\end{array}$ & Italy & IAT & \begin{tabular}{|c|}
$5.01 \%$ \\
moderately \\
$0.79 \%$ seriously \\
addicted
\end{tabular} \\
\hline 10 & Yen et al., 2009 [27] & $\begin{array}{c}2793 \text { people aged } \\
18-48\end{array}$ & Taiwan & CIAS & $12.9 \%$ addicted \\
\hline
\end{tabular}

has also radically changed the way people connect, because internet use is pretty much everywhere.

There are extreme variances in Internet addiction across age, countries and cultures. The prevalence appears higher in younger people, in male gender and in Asian samples. In Eastern societies the Internet has been rapidly developed in recent years. It may suggest that early exposure to the Internet and to environmental factors were important associated factors for Internet addiction. However, the dissimilar rates reported 
can be partially attributed to the use of different classification criteria used. In fact it's possible to use different measure instruments and in some studies the same scales have been used with different cut-off.

The Internet addiction is often associated with comorbid psychiatric disorder (depression, anxiety, ADHD, obsessive-compulsive symptoms, hostility/aggression) and the association is higher than expected by chance.

There is a debate between eastern scientists that are more oriented to accept the diagnosis and western scientists that are critical on the validity of the diagnosis.

Internet addiction remains an ill-defined and heterogeneous construct. Whether Internet addiction is a primary and discrete disorder or whether a part of a larger behavioral syndrome is or whether is manifestation of an underlying disorder is controversial. The research suggests that the disorder and its symptoms are relatively common and are associated with comorbid psychiatric disorders [33].

Finally, is recommended that a clearly defined nosology of Internet addiction is established and to standardize the assessment measures.

\section{Conflict of interest}

The author declares that the research was conducted in the absence of any commercial or financial relationship that could be construed as a potential conflict of interest.

\section{References}

1. Van Rooij AJ, Prause N. A critical review of Internet addiction criteria with suggestions for the future. J. Behav. Addict 3(4), 203-213 (2014).

2. Valentini $M$, Biondi $M$. The emergence of behavioral addictions. Riv. Psichiatr 51(1), 85-86 (2016).

3. Karim R, Chaudhri P. Behavioral addictions: an overview. J. Psychoactive. Drugs 44(1), 5-17 (2012).

4. Sussman S, Lisha N, Griffiths M. Prevalence of the addictions: a problem of the majority or the minority? Eval. Health. Prof 34(1), 3-56 (2011).

5. Kuss DJ, Griffiths MD, Karila L, et al. Internet addiction: a systematic review of epidemiological research for the last decade. Cur. Pharm. Des 20(25), 4026-4052 (2014).

6. Spada MM. An overview of problematic Internet use. Add. Behaviors 39(1), 3-6 (2014).

7. Carli V, Durkee T, Wasserman D et al. The association between pathological Internet use and comorbid psychopathology: a systematic review. Psychopathology 46(1), 1-13 (2013).

8. Shaw M, Black DW. Internet addiction. Definition, assessment, epidemiology and clinical management. CNS. Drugs 22 (5), 353-365 (2008).

9. Shapira N, Goldsmith T, Keck Jr P, et al. Psychiatric features of individuals with problematic Internet use. J. Affect. Disord 57(1-3), 267-272 (2000).

10. American Psychiatric Association Diagnostic and Statistical Manual of mental Disorders (DSM-5). Arlington, VA. American
Psychiatric Association (2013).

11. Ko CH, Yen JY, Yen CF, et al. The association between Internet addiction and psychiatric disorder: a review of the literature. Eur. Psychiatry 27(1), 1-8 (2012).

12. Young KS. Internet addiction: the emergence of a new clinical disorder. Cyberpsycol. Behav 11(1), 237-244 (1998).

13. Block JJ. Issues for DSM-V: Internet addiction. Am. J. Psych 165(3), 306-307 (2008).

14. Griffiths MD. A components model of addiction within a biopsychosocial framework. J. Substance. Use 10(4), 191-197 (2005).

15. Tao $R$, Huang $X$, Wang J, et al. Proposed diagnostic criteria for internet addiction. Addiction 105(3), 556-564 (2010).

16. Chen S, Weng L, Su Y, et al. Development of Chinese internet addiction scale and its psychometric study. Chin. J. Psychol 45(1), 279-294 (2003)

17. Hahn A, Jerusalem M. Validation of an instrument and explorative evidence on personal causes. In: Theobald A, Dreyer M, Starsetzki T, eds. Handbuch zur Online Marktforschung. Beiträge aus Wissenschaft und Praxis. Wiesbaden: Gabler, 213-233 (2001).

18. Ak S, Koruklu N, Yilmaz Y. A study on Turkish adolescent's Internet use: possible predictors of Internet addiction. Cyberpsychol. Behav. Soc. Netw 16(3), 205209 (2013).

19. Anderson KJ. Internet use among college students: an exploratory study. J. Am. Coll. Health 50(1), 21-26 (2001).

20. Bakken IJ, Wenzel HG, Gotestam KG, et al. Internet addiction among Norwegian adults: A stratified probability sample study. Scand. J. Psychol 50(2), 121-127 (2009).

21. Cao F, Su L. Internet addiction among Chinese adolescents: prevalence and psychological features. Child. Care. Health. Dev 33(3), 275-281 (2006).

22. Demetrovics Z, Szeredi B, Rozsa S. The three-factor model of Internet addiction: the development of the problematic internet use questionnaire. Behav. Res. Methods 40(2), 563-574 (2008).

23. Kim K, Ryu E, Chon MY, et al. Internet addiction in Korean adolescents and its relation to depression and suicidal ideation: A questionnaire survey. Int. J. Nursing. Studies 43(2), 185-192 (2006).

24. Ko CH, Yen JY, Chen CS, et al. Predective values of psychiatric symptoms for Internet addiction in adolescents: a 2-year prospective study. Arch. Pediatr. Adolesc Med 163(10), 937-943 (2009).

25. Ni X, Yan H, Chen S, et al. Factors influencing internet addiction in a sample of freshmen university students in China. Cyberpsychol. Behav 12(3), 327-330 (2009).

26. Poli R, Agrimi E. Internet addiction disorder: prevalence in an Italian student population. Nord. J. Psychiatry 66(1), 55-59 (2012).

27. Yen JY, Yen CF, Chen CS. The association between adult ADHD symptoms and Internet addiction among college students: the gender difference. Cyberpsychol. Behav 12(2), 187-191 (2009).

28. Kuss DJ, Lopez-Fernandez OL. Internet addiction and problematic Internet use: A systematic review of clinical research. World. J. Psychiatr 22 (6-1), 143-176 (2016).

29. Kawabe K, Horiuchi F, Ochi M. Internet addiction: prevalence and relation with mental states in adolescents. Psychiatry. 


\section{Internet addiction update: diagnostic criteria, assessment and prevalence Commentary}

Clin. Neurosci 70(9), 405-412 (2016).

30. Lam LT. Risk factors of Internet addiction and the health effect of Internet addiction on adolescents: a systematic review of longitudinal and prospective studies. Curr. Psychiatry. Rep 16(11), 508 (2014).
31. Stip E, Thibault A, Beauchamp-Chatel Ab, et al. Internet addiction, hikikomori syndrome, and the prodromal phase of psychosis. Front. Psychiatry 7: 6 (2016).

32. Krishnamurthy S, Chetlapalli SK. Internet addiction: prevalence and risk factors: a crosssectional study among college students in
Bengaluru, the Silicon Valley of India. Ind. J. Public. Health 59(2), 115-121 (2015).

33. Guedes E, Sancassiani F, Carta MG, et al. Internet addiction and excessive social network use: what about Facebook? Clin. Pract. Epidem. Ment. Health 12(1), 43-48 (2016). 